Pacific Journal of Mathematics

THE FUNCTIONS OF BOUNDED INDEX AS A SUBSPACE OF A
SPACE OF ENTIRE FUNCTIONS 


\section{THE FUNCTIONS OF BOUNDED INDEX}

AS A SUBSPACE OF A SPACE OF

ENTIRE FUNCTIONS

\section{KeIth A. Ekblaw}

Let $f(z)=\sum_{n=0}^{\infty} a_{n} z^{n}$ and $g(z)=\sum_{n=0}^{\infty} b_{n} z^{n}$ be entire functions. Define $d(f, g)=\operatorname{Sup}\left\{\left|a_{0}-b_{0}\right|,\left(\left|a_{n}-b_{n}\right|\right)^{1 / n} n=1,2, \cdots\right\}$. It is the purpose of this note to show that, in the topology generated by $d$, the entire functions of bounded index, $B$, are of the first category.

Further, for $\Gamma$, the corresponding space of all entire functions, and $B_{n}=\{f \in B \mid$ the index of $f$ is $\leqq n\}$ is shown that $B-B_{n}$ is dense in $\Gamma$ for any nonnegative integer $n$. It is also shown that $\Gamma-B$ is dense in $\Gamma$. (For definition and main results see [2], [3].)

Lemma 1. For any $f \in \Gamma, N \geqq 0$, and $\varepsilon>0$ there exists a $\delta>0$ such that if $g \in \Gamma$ and $d(f, g)<\delta$ then $d\left(f^{(k)}, g^{(k)}\right)<\varepsilon$ for $k=0,1, \cdots, N$.

Proof. Let $f(z)=\sum_{n=0}^{\infty} a_{n} z^{n} \in \Gamma, N \geqq 0$, and $\varepsilon>0$ be given. Let

$$
T>\operatorname{Sup}\left\{\left(\frac{(n+k) !}{n !}\right)^{1 / n} \mid n=1,2, \cdots \text { and } k=0,1, \cdots, N .\right\} .
$$

It is straightforward to verify that if $g(z)=\sum_{n=0}^{\infty} b_{n} z^{n} \in \Gamma$ and $d(f, g)<\frac{\varepsilon}{T+\varepsilon}$ then

$$
\begin{aligned}
& d\left(f^{(k)}, g^{(k)}\right) \\
& \quad=\operatorname{Sup}\left\{k !\left|a_{k}-b_{k}\right|,\left(\frac{n+k) !}{n !}\left|a_{n+k}-b_{n+k}\right|\right)^{1 / n} n=1,2, \cdots\right\} \\
& \quad<T \cdot \frac{\varepsilon}{T+\varepsilon}<\varepsilon \text { for } k=0,1, \cdots, N .
\end{aligned}
$$

REMARK. If $f \in \Gamma-B$ then $f$ is said to be of unbounded index and the index of $f=\infty$.

Lemma 2. If $n$ is a nonnegative integer and $f$ is of index $>n$ (bounded or unbounded) then there exists a $\delta>0$ such that if $g \in \Gamma$ and $d(f, g)<\delta$ then $g \in \Gamma-B_{n}$.

Proof. Let $n$ be given such that $n \geqq 0$. Let $f \in \Gamma$ be given such that the index of $f$ (bounded or unbounded) is $>n$. Let $k$ be 
a positive integer $>n$ and $z_{1}$ a complex number such that $f$ is of index $k$ at the point $z_{1}$. Let $\delta_{1}>0$ be such that for

$$
j<k, \frac{\left|f^{(k)}\left(z_{1}\right)\right|}{k !}-\delta_{1}>\frac{\left|f^{(j)}\left(z_{1}\right)\right|}{j !} .
$$

Let $R \geqq\left|z_{1}\right|$. It is known that for every $j \leqq k$ there exists an $\varepsilon_{j}$ such that if $g_{j} \in \Gamma$ and $d\left(f^{(j)}, g_{j}\right)<\varepsilon_{j}$ then $\left|f^{(j)}(z)-g_{j}(z)\right|<\delta_{1} / 2$ for $|z| \leqq R$, and in particular at $z_{1}[1 ; \mathrm{p} .220]$. In Lemma 1 we let $N=k$ and $\varepsilon=\operatorname{Min}\left\{\varepsilon_{0}, \varepsilon_{1}, \cdots, \varepsilon_{k}\right\}$. Hence there exists a $\delta$ such that for $g \in \Gamma$ and $d(f, g)<\delta$ we have

$$
\frac{\left|g^{(k)}\left(z_{1}\right)\right|}{k !}>\frac{\left|g^{(j)}\left(z_{1}\right)\right|}{j !} \text { for } j=0,1, \cdots, k-1 \text {. }
$$

Thus $g$ is of index $\geqq k>n$.

Lemma 3. If $p(z)$ is a polynomial of degree $n$ then $h(z)=e^{z}+p(z)$ is of index $\leqq n+1$.

Proof. Let $k>n+1$. Thus,

$$
\frac{\left|h^{(k)}(z)\right|}{k !}=\frac{\left|e^{z}\right|}{k !}<\frac{\left|e^{z}\right|}{(n+1) !}=\frac{\left|h^{(n+1)}(z)\right|}{(n+1) !}
$$

and hence $h$ is of index $\leqq n+1$.

Theorem 1. For any $n, B_{n}$ is nowhere dense in $B$ and thus $B=\bigcup_{k=0}^{\infty} B_{k}$ is of the first category.

Proof. Let $n$ be given. Lemma 2 shows that $B_{n}$ is closed. Thus let $f \in B_{n}$ and $\varepsilon>0$. Let

$$
e^{z^{2}}=\sum_{k=0}^{\infty} b_{k} z^{k}, f(z)=\sum_{k=0}^{\infty} a_{k} z^{k} \text {, and } f_{j}(z)=\sum_{k=0}^{j} a_{k} z^{k}+\sum_{k=j+1}^{\infty} b_{k} z^{k} .
$$

Since the order of $f_{j}$ is two, for every $j$, we have that $f_{j} \in \Gamma-B$ [3]. Let $i$ be such that $d\left(f, f_{i}\right)<\varepsilon / 2$ and let $f_{i}=\sum_{k=0}^{\infty} c_{k} z^{k}$. For every $j>0$ let $g_{j}(z)=\sum_{k=0}^{j} c_{k} z^{k}+\sum_{k=j+1}^{\infty} z^{k} / k !$. By the previous lemma the index of $g_{j}$ is $\leqq j+1$. Thus, for every $j, g_{j} \in B$. In Lemma 2 we let $\delta<\varepsilon / 2$ be such that if $g \in \Gamma$ and $d\left(f_{i}, g\right)<\delta$ then the index of $g$ is $\geqq n+1$. Let $m$ be such that $d\left(f_{i}, g_{m}\right)<\delta$. Thus $d\left(f, g_{m}\right)<\varepsilon$ and $g_{m} \in B-B_{n}$. Hence, for every integer $n, B_{n}$ is nowhere dense in $B$ and $B=\bigcup_{k=0}^{\infty} B_{k}$ is of the first category.

Theorem 2. The following are dense in $\Gamma$ :

(a) $\Gamma-B$; and

(b) $B-B_{n}$, for any integer $n$. 
Proof. Let $f(z)=\sum_{k=0}^{\infty} a_{k} z^{k} \in \Gamma$.

(a) Let

$$
e^{z^{2}}=\sum_{k=0}^{\infty} b_{k} z^{k}, \text { and } f_{j}=\sum_{k=0}^{j} a_{k} z^{k}+\sum_{k=j+1}^{\infty} b_{k} z^{k} .
$$

As in the proof of Theorem $1, f_{j} \in \Gamma-B$ for every $j$ and $\lim _{j \rightarrow \infty} d\left(f, f_{j}\right)=0$.

(b) Now let

$$
f_{j}(z)=\sum_{k=0}^{j} a_{k} z^{k}+\sum_{k=j+1}^{\infty} \frac{z^{k}}{k !} .
$$

By Lemma $3, f_{j}$ is of bounded index for every $j$. For each $j$, if the index of $f_{j}$ is $>n$ let $g_{j}=f_{j}$. If the index of $f_{j}$ is $\leqq n$ then by Theorem 1 there exists a function $g \in B-B_{n}$ such that $d\left(f_{j}, g\right)<1 / j$. Let $g_{j}=g$. Hence the $\lim _{j \rightarrow \infty} d\left(f, g_{j}\right)=0$ and for every $j, g_{j} \in B-B_{n}$. In conclusion it should be noted that the polynomials could be excluded from the class of entire functions, $\Gamma$, and the proofs of the preceeding Lemmas and Theorems would remain valid.

\section{REFERENCES}

1. C. Goffman and G. Pedrick, First Course in Functional Analysis, Prentice-Hall, Inc., 1965.

2. F. Gross, Entire functions of bounded index, Proc. Amer. Math. Soc., 18 (1967), 974-980.

3. S. M. Shah, Entire functions of bounded index, Proc. Amer. Math. Soc., 19 (1968), 1017-1022.

Received October 19, 1970 and revised form January 11, 1971. The results in this note form a part of the authors doctoral dissertation at the University of Kentucky prepared under the supervision of Professor S. M. Shah.

Boise State College 



\section{PACIFIC JOURNAL OF MATHEMATICS}

\section{EDITORS}

\author{
H. SAMElson \\ Stanford University \\ Stanford, California 94305 \\ C. R. HOBBY \\ University of Washington \\ Seattle, Washington 98105
}

J. DugundjI

Department of Mathematics University of Southern California Los Angeles, California 90007

RICHARD ARENS

University of California

Los Angeles, California 90024

\section{ASSOCIATE EDITORS}
E. F. BECKENBACH
B. H. NeUmanN
F. WOLE
K. YOSHIDA

\section{SUPPORTING INSTITUTIONS}

\author{
UNIVERSITY OF BRITISH COLUMBIA \\ CALIFORNIA INSTITUTE OF TECHNOLOGY \\ UNIVERSITY OF CALIFORNIA \\ MONTANA STATE UNIVERSITY \\ UNIVERSITY OF NEVADA \\ NEW MEXICO STATE UNIVERSITY \\ OREGON STATE UNIVERSITY \\ UNIVERSITY OF OREGON \\ OSAKA UNIVERSITY \\ UNIVERSITY OF SOUTHERN CALIFORNIA
}

\author{
STANFORD UNIVERSITY \\ UNIVERSITY OF TOKYO \\ UNIVERSITY OF UTAH \\ WASHINGTON STATE UNIVERSITY \\ UNIVERSITY OF WASHINGTON \\ * * * \\ AMERICAN MATHEMATICAL SOCIETY \\ CHEVRON RESEARCH CORPORATION \\ NAVAL WEAPONS CENTER
}

The Supporting Institutions listed above contribute to the cost of publication of this Journal, but they are not owners or publishers and have no responsibility for its content or policies.

Mathematical papers intended for publication in the Pacific Journal of Mathematics should be in typed form or offset-reproduced, (not dittoed), double spaced with large margins. Underline Greek letters in red, German in green, and script in blue. The first paragraph or two must be capable of being used separately as a synopsis of the entire paper. The editorial "we" must not be used in the synopsis, and items of the bibliography should not be cited there unless absolutely necessary, in which case they must be identified by author and Journal, rather than by item number. Manuscripts, in duplicate if possible, may be sent to any one of the four editors. Please classify according to the scheme of Math. Rev. Index to Vol. 39. All other communications to the editors should be addressed to the managing editor, Richard Arens, University of California, Los Angeles, California, 90024.

50 reprints are provided free for each article; additional copies may be obtained at cost in multiples of 50 .

The Pacific Journal of Mathematics is published monthly. Effective with Volume 16 the price per volume (3 numbers) is $\$ 8.00$; single issues, $\$ 3.00$. Special price for current issues to individual faculty members of supporting institutions and to individual members of the American Mathematical Society: $\$ 4.00$ per volume; single issues $\$ 1.50$. Back numbers are available.

Subscriptions, orders for back numbers, and changes of address should be sent to Pacific Journal of Mathematics, 103 Highland Boulevard, Berkeley, California, 94708.

PUBLISHED BY PACIFIC JOURNAL OF MATHEMATICS, A NON-PROFIT CORPORATION

Printed at Kokusai Bunken Insatsusha (International Academic Printing Co., Ltd.), 7-17, Fujimi 2-chome, Chiyoda-ku, Tokyo, Japan. 


\section{Pacific Journal of Mathematics}

\section{Vol. 37, No. $2 \quad$ February, 1971}

Charles Compton Alexander, Semi-developable spaces and quotient images of metric spaces .................................... 277

Ram Prakash Bambah and Alan C. Woods, On a problem of Danzer. . . . . . . . . 295

John A. Beekman and Ralph A. Kallman, Gaussian Markov expectations and related integral equations . ....................................

Frank Michael Cholewinski and Deborah Tepper Haimo, Inversion of the Hankel

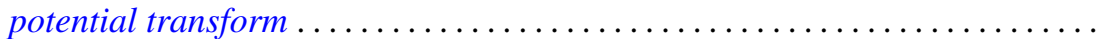

John H. E. Cohn, The diophantine equation

$$
Y(Y+1)(Y+2)(Y+3)=2 X(X+1)(X+2)(X+3) \ldots \ldots \ldots \ldots \ldots
$$

Philip C. Curtis, Jr. and Henrik Stetkaer, A factorization theorem for analytic

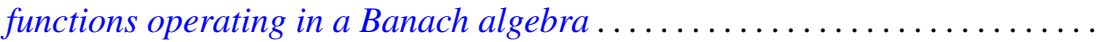

Doyle Otis Cutler and Paul F. Dubois, Generalized final rank for arbitrary limit ordinals

Keith A. Ekblaw, The functions of bounded index as a subspace of a space of entire functions

Dennis Michael Girard, The asymptotic behavior of norms of powers of

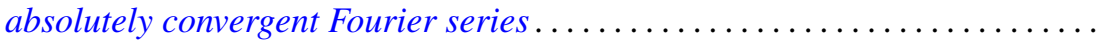

John Gregory, An approximation theory for elliptic quadratic forms on Hilbert spaces: Application to the eigenvalue problem for compact quadratic forms. 383

Paul C. Kainen, Universal coefficient theorems for generalized homology and stable cohomotopy.

Aldo Joram Lazar and James Ronald Retherford, Nuclear spaces, Schauder bases, and Choquet simplexes.

David Lowell Lovelady, Algebraic structure for a set of nonlinear integral operations

John McDonald, Compact convex sets with the equal support property . 429

Forrest Miller, Quasivector topologies

Marion Edward Moore and Arthur Steger, Some results on completability in commutative rings.

A. P. Morse, Taylor's theorem

Richard E. Phillips, Derek J. S. Robinson and James Edward Roseblade, Maximal subgroups and chief factors of certain generalized soluble groups.

Doron Ravdin, On extensions of homeomorphisms to homeomorphisms ...

John William Rosenthal, Relations not determining the structure of $\mathrm{L}$

Prem Lal Sharma, Proximity bases and subbases ........... .

Larry Smith, On ideals in $\Omega_{*}^{u}$. .

Warren R. Wogen, von Neumann algebras generated by operators similar to normal operators

R. Grant Woods, Co-absolutes of remainders of Stone-Čech 